\title{
The pathogenesis of tibial non-union
}

\author{
N Ferreira ${ }^{1}$ BSc, MBChB, FC Orth(SA), MMed(Orth), PhD \\ LC Marais ${ }^{1}$ MBChB, FCS Orth(SA), MMed(Ortho), PhD \\ C Aldous ${ }^{2}$ BSc, BSc(Hons), MSc, PhD \\ ${ }^{1}$ Tumour Sepsis and Reconstruction Unit, Department of Orthopaedic Surgery, Grey's Hospital, \\ Nelson R. Mandela School of Medicine, University of KwaZulu-Natal \\ ${ }^{2}$ Medical Research Scientist, School of Clinical Medicine, College of Health Sciences, University of KwaZulu-Natal \\ Corresponding author: \\ Dr Nando Ferreira \\ Department of Orthopaedic Surgery \\ Grey's Hospital \\ 3201 Pietermaritzburg \\ KwaZulu-Natal \\ South Africa \\ Tel: +27338973000 \\ Email: Nando.Ferreira@kznhealth.gov.za
}

\begin{abstract}
Bone healing is a unique and complex reparative process that results in fractures healing without scar tissue formation. Multiple factors have been implicated in altering this process. This paper reviews the factors that influence the process of bone healing and predispose to non-union development. Cognisance of these factors will assist orthopaedic surgeons in identifying fractures at risk of altered healing and guide the development of comprehensive management strategies for established non-unions.
\end{abstract}

Key words: tibia, non-union, pathogenesis, fracture, healing

http:/ / dx.doi.org/10.17159/2309-8309/2016/v15n1a5

\section{Introduction}

The human body has evolved the ability to spontaneously heal skeletal injuries through secondary bone healing and callus formation. This is evident from healed fractures observed in Homo neaderthalensis and Homo erectus fossils. ${ }^{1,2}$ This healing process is unique in nature as most tissues heal with scar tissue formation, while skeletal tissue repairs with bone that is histologically indistinguishable from the original bone.

Manipulating this natural healing process in order to ensure proper alignment, maintenance of limb length and faster return to function, has been the goal of physicians throughout the ages. The Edwin Smith Papyrus from ancient Egypt is the oldest existing medical text and describes in detail the splinting of extremity fractures to preserve function. ${ }^{3}$

Non-union occurs when this natural healing process is hampered or disrupted and is one of the most dreaded complications of fracture management. Non-union following tibial shaft fractures represents the most common long-bone non-unions that require treatment. ${ }^{4}$ Quoted incidences range from $4 \%$ to $48 \%$ and an established non-union signals a significant impact on a patient's function and quality of life. ${ }^{4-9}$
Multiple factors have been implicated in the pathogenesis of long-bone non-unions. ${ }^{7,10,11}$ Recognising these factors will help refine strategies aimed at prevention of non-union and may guide the management of established non-unions. In this review we explore the factors that influence normal bone healing and predispose to non-union development after a tibial shaft fracture.

\section{Normal bone healing}

Bone healing is a complex cascade of events that results in the repair of fractures without the formation of scar tissue and can be classified into two histological types, namely primary and secondary bone healing. . $^{1213}$

Primary bone healing ('soudure autogene') involves direct cortical remodelling through the formation of cutting cones that cross the fracture gap. ${ }^{13}$ This type of bone healing occurs when there is a combination of anatomical reduction, stable fixation and compression of the fracture site and is only seen with open reduction and rigid internal fixation.

Secondary bone healing represents the most common type of fracture healing and occurs when there is some motion at the fracture site, which induces callus formation. During this healing process both endochondral and intramembranous ossification occur in an ordered sequence divided into three phases..$^{13}$ 
The first phase starts with a haematoma that forms after the injury. This initiates an inflammatory response with the release of cytokines, including platelet derived growth factor (PDGF), TNF- $\alpha$ and interleukins from macrophages, neutrophils and platelets. These cytokines are responsible for the recruitment of fibroblasts and pluripotent mesenchymal cells that migrate to the fracture site. Granulation tissue forms around the fracture ends, and osteoblasts and fibroblasts proliferate. This is followed by the reparative phase when primary callus is formed. The mechanical environment drives differentiation of either osteoblastic or chondroblastic cell lines. Endochondral ossification mineralises a chondroid matrix while woven bone is generated through mineralisation of an osteoid matrix. The final stage involves remodelling the healed fracture site. This process is governed by Wolff's Law in response to mechanical stresses on the bone.

\section{Mechano-biology}

The mechanical environment plays a major role in fracture healing and can be described in terms of inter-fragmentary motion and strain. ${ }^{14,15}$ While a small amount of relative deformation (strain $<2 \%$ ) induces callus formation, high strain $(>10 \%)$ will lead to bone resorption and eventual non-union. ${ }^{14}$ The amount of mobility allowed depends less on the displacement of the fragments alone than on the relation of the width of the fracture gap (L) and displacement $(\delta \mathrm{L}) ; \delta \mathrm{L} / \mathrm{L} .{ }^{15}$

Mechanical stimulation also has a direct effect on the physiology of fracture healing. Ilizarov stated that functional load determines the structure, shape and volume of any limb. This is due to an increase in local blood flow during functional use that aids in tissue growth. ${ }^{5}$ Mechanical stimulation also directly influences bone biology on a cellular level by stimulating the proliferation and differentiation of osteoblasts. ${ }^{5,16}$ Mechanical force application patterns, as well as loading magnitude and frequency, also affect bone healing on a biochemical level. ${ }^{16}$ The rates of synthesis and degradation of extracellular matrix components are affected by force application patterns. Loading magnitude affects cell size through increasing amounts of intermediate filaments and glycogen particles while changes in loading frequency can alter mRNA synthesis of anabolic and catabolic genes. ${ }^{16}$ Aggrecan gene expression is increased in response to mechanical stimulation and leads to an increased proteoglycan scaffold for type II collagen. ${ }^{5}$

Mechanical stimulation has further benefits in terms of union site remodelling according to Wolff's Law. This phenomenon was originally ascribed to piezo-electrical charges that are generated in response to mechanical stresses. Osteoblasts on the compressive side are stimulated by electronegative charges while osteoclasts are activated by electropositive charges on the tension side. ${ }^{17,18}$ This explanation is likely an oversimplification of a complex mechanism that regulates bone remodelling. ${ }^{19}$
Current understanding of bone mechanosensation involves strain-generated potentials to explain how bone is able to respond to mechanical stresses.

\section{Injury factors}

The tibia is the most commonly fractured long bone. ${ }^{4}$ Its anatomical location exposes it to high energy trauma and its thin soft tissue envelope means that these injuries are frequently open fractures..$^{20}$ This, along with a tenuous blood supply and complex fracture patterns that are frequently seen after high energy injuries predispose tibial fractures to complications that affect fracture healing. ${ }^{5,8,13,20}$

In an observational study of 200 patients, Bhandari et al. identified open fractures and transverse fracture patterns as independent variables that predict re-operation following tibial shaft fractures..$^{21}$ In this study, re-operation was defined as any surgical procedure aimed specifically at achieving bony union. In a more recent study, Fong et al. identified open fractures, comminution, fracture with less than $25 \%$ cortical contact, oblique fracture pattern and segmental fractures to be associated with non-union development. After multivariable logistic regression analysis only cortical contact of less than $25 \%$ remained as a variable that was a strong predictor of non-union and re-operation. ${ }^{8}$

The thin soft tissue envelope of the tibia is frequently breached during high energy trauma leading to these injuries being the most common open fractures managed by orthopaedic surgeons. ${ }^{20}$ Open fractures result in loss of the initial fracture haematoma, periosteal stripping and ischaemic bone and soft tissues. ${ }^{11}$ These factors contribute to an increased risk of non-union development in open fractures. Gaebler et al. found that grade III open fractures were five times more likely to develop delayed union compared to closed grade I and grade II fractures. ${ }^{22}$ In a review of 104 patients, Karladani et al. reported a relative risk of 8.2 (95\% confidence interval) for developing non-union in open fractures. ${ }^{23}$ Gaston et al. reviewed 100 patients with tibial shaft fractures. They also reported a higher risk of nonunion after open fractures with a relative risk of $3.4(95 \%$ confidence interval). ${ }^{24}$

Atrophic non-unions in particular appear to be related to the extent of the initial damage sustained. ${ }^{11,25}$ Injuries that result in extensive soft tissue damage, severe fracture comminution and devitalisation of fracture fragments have an increased risk of atrophic non-union. ${ }^{5,25-27}$ Gaston et al. found that comminuted fractures had a higher likelihood of altered healing. They reported that Winquist and Hansen type III and IV tibial shaft fractures had 31\% and 38\% chance of non-union respectively compared to type I and II fractures that had an $8 \%$ chance of non-union each. ${ }^{24}$ These high energy injuries appear to disrupt the vascularity of the fracture ends and affect the early stages of fracture healing. ${ }^{11,28,29}$ In a rabbit model for atrophic non-union, the vascularity of the fracture site during the early stages of fracture healing was implicated as the driving force for atrophic non-union development. 
This study found that although the non-union site appeared well vascularised at eight and 16 weeks, no vessels were seen within the interfragmentary gap at one week following the injury. ${ }^{30}$

The specific injury characteristics and damage sustained at the time of injury cannot be modified by the surgeon. Early identification of high-risk injury patterns should however prompt the treating surgeon to employ management algorithms that increase the chances of obtaining union.

\section{Fracture management}

Surgical intervention may inadvertently increase the chances of fracture non-union; the choice of fixation and the way in which it is executed can contribute to the overall risk of non-union. Fractures fixed in distraction, unstable fixation and excessive soft tissue dissection all contribute to an increased risk of non-union development. ${ }^{13,25}$

For fractures to heal, the mechanical environment must be appropriate. ${ }^{31}$ Obtaining the ideal inter-fragmentary strain is of vital importance. Bhandari et al. identified fixation with a fracture gap as an independent risk factor for requiring additional surgery to achieve union. ${ }^{21}$ Fracture gaps may potentially cause non-unions along two pathways. Unstable fixation coupled with small fracture gaps result in a high strain environment that favours chondroid and fibrous differentiation over osteogenesis. ${ }^{25}$ Exposing the initial soft callus to excessive motion may disrupt the reparative phase of fracture healing and may result in a hypertrophic non-union. ${ }^{27,32}$ On the other hand, fractures that are rigidly fixed in distraction may result in such low inter-fragmentary strain that no callus formation is stimulated. These situations often result in atrophic nonunions and fixation failure.

The optimal mechanical environment is however not the only consideration when deciding on fixation method, as this should be offset against preserving the remaining biological potential to unite. Open reduction and internal fixation might further disrupt a tenuous blood supply, especially in tibial fractures with concomitant soft tissue injury. Excessive stripping of soft tissue and periosteum may exacerbate necrosis of bone ends and contribute to the loss of biological potential to heal, ultimately resulting in an atrophic non-union. ${ }^{25,29}$ Following high energy tibial fractures it might therefore be prudent to follow management strategies that preserve the local biological environment.

\section{Host factors}

Not all patients have the same fracture-healing potential. Some individuals have great ability to heal fracture gaps that might proceed to non-union in another person. The factors that contribute to impaired fracture healing include age, gender and certain concomitant systemic illnesses.?

\section{Age}

Age has a major influence on the body's ability to heal injuries. Children have a thick periosteum and an osteogenic environment dedicated to skeletal growth. This results in large haematomas and rapid callus formation after paediatric injuries. ${ }^{33}$ As skeletally mature individuals advance in age a significant impact on skeletal repair is observed. ${ }^{34,35}$ As a result, the observed healing time of fractures in the paediatric population is about half that in adults. Although there is no correlation between gender and non-union of fractures, healing problems are common among males since they have a higher incidence of high energy fractures. ${ }^{31}$

\section{Concomitant systemic disease}

- Anaemia: Low haemoglobin affects aerobic metabolic processes and alters the body's ability to repair injuries following trauma. Two animal studies investigated the effect of anaemia on fracture healing. Rothman et al. reported that iron-deficient anaemic rats had poor mineralisation of fracture callus and a decreased rate of union. ${ }^{36,37}$ Heppenstall et al. found that hypovolaemic, anaemic rabbits showed inhibition of fracture healing but after fluid resuscitation, normovolaemic anaemic rabbits had no adverse effects. ${ }^{38}$ Varecka et al. conducted a retrospective review of 734 patients and concluded that patients with a haemoglobin level below $8 \mathrm{~g} / \mathrm{dL}$ had an increased risk of non-union. This was particularly significant in tibial fractures. In their series, patients that were smokers combined with anaemia had a $100 \%$ risk of nonunion. $^{39}$

- Malnutrition: Dietary and metabolic requirements increase during fracture healing. ${ }^{11,25,31}$ Brinker et al. found that $85 \%$ of patients who developed unexplained nonunions had an underlying, undiagnosed metabolic or endocrine abnormality. The most common of which were vitamin $\mathrm{D}$ deficiencies. ${ }^{10}$ Dodds et al. showed that vitamin B6-deficient rats had significant delays in callus maturation. ${ }^{40}$ Osteoblast function has further been shown to be dependent on vitamin $\mathrm{C}^{41}$ In order to optimise fracture healing, patients should undergo careful nutritional assessment and any identified deficiencies should be addressed.

- Diabetes: Several clinical and experimental studies have shown that diabetes impairs bone healing. ${ }^{31,42}$ Multiple animal studies using either rats with streprozotocininduced diabetes or BB Wistar type I diabetic rats have investigated the effects of diabetes on fracture healing. These rats all show decreased callus stiffness and tensile strength in the early stages of fracture healing. ${ }^{43,44}$ Diabetic rats were also found to have decreased cell proliferation, decreased collagen content and increased rates of cartilage resorption at the fracture site compared to controls. ${ }^{43,45-47}$ Follak et al. showed that tight glycaemic control can produce normal fracture healing. ${ }^{48} \mathrm{~A}$ study by Gandhi et al. further indicated that insulin might even play a direct role in healing at the fracture site. ${ }^{49}$ 
- Hypothyroidism: Urabe et al. investigated femur fracture healing in hypothyroid rats. They observed impaired healing as a result of deficient endochondral ossification. When these rats were treated with L-thyroxine, the healing process was returned to normal. ${ }^{50}$

The message from all these studies is clear: when confronted with a non-union, physicians should screen patients for these potential co-morbidities and all reversible or modifiable risk factors should be optimised during the healing process.

\section{Smoking}

Study data have conclusively revealed that smoking is associated with longer healing times, increased non-union rates and more wound complications after long-bone fractures. ${ }^{26,51-54}$ The impact of smoking appears to be particularly pronounced in open tibial fractures. ${ }^{55,56}$

Several mechanisms have been proposed to explain how smoking impairs fracture healing and include alterations on a vascular, cellular and intracellular level. Smoking causes vasoconstriction and local hypoxia that could predispose the patient to atrophic non-union development. ${ }^{11,57,58}$ Nicotine in tobacco prevents cellular proliferation, alters macrophage and fibroblast maturation and is directly toxic to proliferating osteoblasts. ${ }^{11,31,59}$ Nicotine further inhibits TNF- $\alpha$ expression, required for fracture healing, through the activation of the cholinergic antiinflammatory pathway. ${ }^{60}$ On an intracellular level, smoking inhibits alkaline phosphatase and collagen production. ${ }^{25}$

Cobb et al. performed a case control study with patients undergoing ankle arthrodesis. They reported a relative risk of 3.74 for non-union in active smokers. When they analysed the patients without any other known risk factor for non-union development, the risk for non-union in smokers was 16 times that of non-smokers. ${ }^{61}$ Bhandari et al. reported overall union rates of tibial shaft fractures to be higher in non-smokers (94\%) when compared to smokers $(84 \%){ }^{21}$ Adams et al. showed that smokers had increased healing times after tibial fractures (32 weeks vs 28 weeks), required more bone graft procedures (26\% vs $18 \%)$ and had a higher rate of non-unions, flap breakdown and infection. ${ }^{55}$ A recent meta-analysis by Schenker et al. confirmed that the mean healing time for tibia fractures was longer for smokers (32 weeks) than for non-smokers (25 weeks) and that smokers with tibia fractures or open fractures had increased rates of non-union. ${ }^{62}$

Cessation of smoking may not result in an immediate improvement. Castillo et al. investigated patients who sustained open tibia fractures and found that current smokers were $37 \%$ and previous smokers $32 \%$ less likely to achieve union than non-smokers. ${ }^{63}$

It is clear from the available evidence that smoking negatively impacts healing of tibia fractures. It further appears that previous smoking negatively impacts outcome but to a lesser extent than current smoking. The question that remains to be answered is the time needed for the negative effects of smoking to dissipate after cessation of smoking. It is however prudent for physicians to encourage patients with acute fractures, and patients undergoing treatment for established non-unions, to stop smoking.

\section{NSAIDs}

Non-steroidal anti-inflammatory drugs (NSAIDs) are frequently used to manage post-traumatic or postoperative pain. They inhibit cyclooxygenase (COX) enzyme activity and decrease prostaglandin production, which may have a detrimental effect during the inflammatory phase of fracture healing. Conflicting evidence about their effect in clinical practice however remains. ${ }^{64,65}$ Multiple clinical trials have failed to provide a definitive answer to the effect of NSAIDs on fracture healing. ${ }^{66}$ Burd et al., Giannoudis et al. and Bhattacharyya et al. all reported significant risk for non-union of long bone fractures with the use of NSAIDs. ${ }^{67-69}$ Davis et al. and Adolphson et al., however, failed to show any correlation between the use of NSAIDs and abnormal fracture healing. ${ }^{70,71}$ It is notable however that both these studies were conducted on patients who sustained Colles' fractures that generally are unlikely to develop non-unions. Studies investigating the effect of NSAIDs on spinal fusion also failed to provide conclusive answers, with some studies showing an inhibitory effect toward fusion while others contradict these findings. ${ }^{72-76}$

In vitro and animal studies has shown similar variations in outcome. ${ }^{64,65}$ The diversity in study design may have contributed to the lack of consensus, but even studies with identical study parameters sometimes report contradictory findings.

Conclusive evidence against the use of NSAIDs in acute fracture care cannot be drawn from the available evidence. The lack of evidence is, however, not proof of the absence of a detrimental effect and these drugs should be used with caution in patients with high-risk for abnormal fracture healing. ${ }^{64}$

\section{Other drugs}

- Antibiotics: Animal and in vitro evidence indicate that antibiotic therapy may have adverse effects on fracture healing. ${ }^{77-79}$ The quinolones, ciprofloxacin, levofloxacin and trovafloxacin have been shown to decrease cellular proliferation and DNA synthesis which result in diminished healing during the early stages of fracture repair. ${ }^{77,78}$ The aminoglycosides gentamycin and tobramycin decrease proliferation of osteoblastic progenitors and are directly toxic to osteoblasts..$^{80,81}$ Experimental studies have shown that osteoblast proliferation might be inhibited by rifampicin at clinical doses. ${ }^{82}$ There is however little evidence on the effect of antibiotic therapy on fracture healing in humans. ${ }^{79}$ 
- Anticoagulants: In vitro and in vivo evidence suggest that some anticoagulants may impair normal bone metabolism. ${ }^{83-85}$ Several animal studies have demonstrated significant attenuation of fracture healing but no human trials are available for evaluation. ${ }^{531,83,85} \mathrm{~A}$ literature review by Lindner et al. identified strong evidence that warfarin and heparin retard fracture healing, but low molecular weight heparins appear to have a less pronounced effect. ${ }^{86}$

- Anticonvulsants: There is a growing body of evidence on the adverse effects of anticonvulsants in bone metabolism. Phenytoin, phenobarbital, carbamazepine primidone and valproate have all been implicated in causing decreased bone mineral density and disorders of bone metabolism. ${ }^{87-91}$ The extent to which these drugs affect fracture healing in humans remains to be evaluated.

- Chemotherapy: Chemotherapeutic agents significantly affect fracture healing. Their cytotoxic and anti-proliferative properties impact neovascularisation and callus formation resulting in higher non-union rates. ${ }^{31,92}$ Cyclophosphamide causes diminished calcium and phosphate deposition in callus. ${ }^{93}$ Doxorubicin, cyclophosphamide, adriamycin and methotrexate results in decreased bone formation and these effects might last up to three weeks after administration..$^{93}$

- Corticosteroids: The effect of long-term corticosteroid use on bone metabolism and fracture healing is well documented. ${ }^{31,94,95}$ The long-term use of corticosteroids leads to osteoblast and osteocyte apoptosis and inhibition of osteoblastogenesis. ${ }^{5,1,92}$ Waters et al. studied the effects of long-term steroid use on fracture healing in a rabbit model. They found an $85 \%$ rate of non-union in the corticosteroid group compared with $18 \%$ in the control group. ${ }^{94}$ In contrast, Hogevold et al. investigated shortterm corticosteroids use on fracture healing in rats and found no statistically significant difference when compared to a control group. ${ }^{96}$

\section{Alcohol}

Chronic alcohol consumption leads to osteopaenia, increased risk of fracture from falls and delays in fracture healing. ${ }^{97}$ Many of these problems have been attributed to nutritional deficiencies and biochemical derangements frequently observed in chronic alcohol abuse.

Recent research has, however, illustrated that excessive alcohol use may have a direct impact on bone healing. It appears that excessive doses of ethanol in the early healing period inhibit new bone formation and that the newly formed bone lacks mineralisation, causing decreased stability and leading to increased incidence of delayed union. ${ }^{5,11,31,92}$

Experimental evidence from ethanol exposed fracture healing in murine models indicates that ethanol impairs the biomechanical strength and decreases the volume of callus formation. ${ }^{98-100}$ Chakkalakal et al. studied the effects of ethanol on a fracture model in rats. They found that rats that were fed ethanol as $35 \%$ of their total calorie intake had deficient bone repair that could not be attributed to nutritional deficiencies. They further found that removal of ethanol from the diet after the bone injury completely restored bone healing. ${ }^{99}$

A retrospective study by Askew et al. was consistent with these animal findings. The investigators compared the healing time of fractures in 12 alcoholics and 18 nonalcoholics and found delayed healing time in alcoholics of more than twice that of non-alcoholics. ${ }^{101}$

These studies indicate that alcohol might have a direct negative effect on fracture healing. It appears, however, that these effects could be negated by the early cessation of alcohol intake following an injury.

\section{Infection}

Sepsis is often cited as a cause of non-union development. ${ }^{13}$ Infection and non-union does not, however, have a simple cause-and-effect relationship. Many factors that promote infection, like open wounds with extensive devascularisation, tissue necrosis and instability, are also implicated in non-union development. ${ }^{11,25}$ Infection can however contribute to non-union development through bone death, creation of fracture gaps due to bone resorption, and instability because of implant loosening. ${ }^{25}$

\section{Human Immunodeficiency Virus}

HIV infection has recently been disputed as a risk factor for non-union development. Initial studies showed an increased risk for non-union in certain HIV-positive subgroups. Kamat and Govender evaluated the effect of HIV infection on union rates of closed ankle fractures that were managed non-operatively. They concluded that there was no difference in union rates of HIV-negative and WHO clinical stage I, II and III HIV-positive patients, while patients with WHO clinical stage IV HIV infection had increased non-union rates. $(12.45 \%$ vs $1.5 \%$ and $1.25 \%)^{102}$ Chandanwale et al. compared healing rates in 80 HAART naive HIV-positive patients with $80 \mathrm{HIV}$-negative controls. Closed fractures had similar healing rates in the two groups when treated conservatively or operatively. Open fractures in the HIV-positive group, on the other hand, showed a significantly increased risk of non-union. $(50 \% \text { vs } 15 \%)^{103}$ Aird et al. prospectively evaluated 133 patients (33 HIV-positive) with open fractures. They reported a non-union risk of $15 \%$ in HIV-positive patients compared to $4 \%$ in HIV-negative patients. ${ }^{104}$

More recent research has contradicted these earlier findings. Gardner et al. prospectively evaluated union in 96 HIV-positive patients. They reported that $4 \%$ of these fractures failed to unite and concluded that HIV infection did not increase the risk of non-union in surgically managed fractures. This cohort, however, included only five open fractures. ${ }^{105}$ 
The exact mechanisms by which HIV infection affects fracture union remain unclear although multiple pathways have been suggested. Molecular and biochemical hypotheses could explain a direct relationship between HIV and impaired fracture union. HIV infection is known to cause an altered cytokine environment that may impact bone healing. TNF- $\alpha$ is up regulated while IGF-1 levels are reduced and an inverse correlation between IGF-1 and IL-6 is observed when compared to HIV-negative individuals. ${ }^{106}$ HIV may further affect fracture healing by its impact on general health through malnutrition, reduced body mass and opportunistic infections.

Considering the limited and controversial evidence regarding fracture healing in HIV-infected individuals, it might be well advised to take particular care to optimise bone healing in HIV-positive patients. A tailored fracture management strategy, improvement of nutritional status, avoidance of NSAIDs and cessation of smoking and alcohol consumption might assist in mitigating the potential negative effects of HIV infection on bone healing.

\section{Genetics}

Despite the lack of any apparent risk factors, some patients still proceed to non-union development. ${ }^{107}$ This has led to the hypothesis of a genetic predisposition to altered fracture healing. ${ }^{108}$

Zeckey et al. identified a significant correlation between polymorphisms in the PDGF gene and non-union development after femoral and tibial shaft fractures. ${ }^{109}$ Dimitriou et al. investigated the impact of genetic defects in the BMP signalling cascade on non-union development. The study identified two specific single nucleotide polymorphisms on the NOGGIN and SMAD6 genes that were associated with an increased risk for atrophic nonunion development. ${ }^{110}$ Fajardo et al. examined RNA expression patterns of BMPs, their receptors and inhibitors in hypertrophic non-union tissue. They found substantially elevated concentrations of BMP-4 and certain BMP inhibitors (Drm/Gremlin, follistatin and Noggin) while levels of BMP-7 was lower than those seen in normal fracture healing. ${ }^{111}$

The extent to which these genetic components predispose to non-union formation, and their role and interaction with other risk factors, warrant further investigation.

\section{Conclusion}

Non-union development has a multifactorial pathogenesis that is not well understood. The weight that each variable contributes to non-union development remains unclear and a cumulative effect to the development of a non-union is probably involved. A greater understanding of the contributing factors to non-union development will assist orthopaedic surgeons in identifying fractures at risk of altered healing, and assist in the development of multidisciplinary management strategies for established non-unions.

\section{Conflict of interest statement}

The authors declare that they have no conflict of interests and that no financial support was received for this study.

\section{Authors' contributions}

All three authors made contributions toward the conception and design of the research, acquisition of data and drafting of the manuscript. The final manuscript was read and approved by all the authors.

\section{References}

1. Stewart TD. The restored Shanidar I skull. Smithsonian Inst Report. 1959:473-80.

2. Ascenzi A, Benvenuti A, Segre A. On the paleopathologic findings exhibited by the late Homo erectus of Ceprano, Italy. Hum Evol. 1997;12(3):189-96.

3. Brorson S. Management of fractures of the humerus in Ancient Egypt, Greece, and Rome: an historical review. Clin Orthop Relat Res. 2009;467(7):1907-14. PubMed PMID: 19002538. Pubmed Central PMCID: 2690737.

4. Antonova E, Kim Le T, Burge R, Mershon J. Tibia Shaft fracture - costly burden of nonunions. BMC Musculoskelet Disord. 2013;14:42.

5. Bhandari M, Schemitsch E. Clinical advances in the treatment of fracture nonunion: the response to mechanical stimulation. Curr Opin Orthop. 2000;11:372-7.

6. Audige L, Griffin D, Bhandari M, Kellam J, Ruedi TP. Path analysis of factors for delayed healing and nonunion in 416 operatively treated tibial shaft fractures. Clin Orthop Relat Res. 2005;438:221-32.

7. Harwood P, Newman J, ALR. M. An update on fracture healing and non-union. Orthop Trauma. 2010;24(1):9-23.

8. Fong K, Truong V, Foote CJ, Petrisor B, Williams D, Ristevski $\mathrm{B}$, et al. Predictors of nonunion and reoperation in patients with fractures of the tibia: an observational study. BMC Musculoskelet Disord. 2013;14:103. PubMed PMID: 23517574. Pubmed Central PMCID: 3614478.

9. Mills LA, Simpson AH. The relative incidence of fracture nonunion in the Scottish population (5.17 million): a 5-year epidemiological study. BMJ open. 2013;3(2). PubMed PMID: 23396560. Pubmed Central PMCID: 3586107.

10. Brinker MR, O'Connor DP, Monla YT, Earthman TP. Metabolic and endocrine abnormalities in patients with nonunions. J Orthop Trauma. 2007;21(8):557-70. PubMed PMID: 17805023.

11. Calori GM, Albisetti W, Agus A, Iori S, Tagliabue L. Risk factors contributing to fracture non-unions. Injury. 2007;38 Suppl 2:S11-8. PubMed PMID: 17920412.

12. McKibbin B. The biology of fracture healing in long bones. $J$ Bone Joint Surg [Br]. 1978;60-B(2):150-62. PubMed PMID: 350882.

13. Webb J, Tricker J. A review of fracture healing. Curr Orthop. 2000;14:457-63.

14. Perren SM. Physical and biological aspects of fracture healing with special reference to internal fixation. Clin Orthop Relat Res 1979;(138):175-96. PubMed PMID: 376198.

15. Perren SM. Evolution of the internal fixation of long bone fractures. The scientific basis of biological internal fixation: choosing a new balance between stability and biology. J Bone Joint Surg [Br]. 2002;84(8):1093-110. PubMed PMID: 12463652. 
16. Chen JC, Carter DR. Important concepts of mechanical regulation of bone formation and growth. Curr Opin Orthop. 2005;16:338-45.

17. Bassett CA, Becker RO. Generation of electric potentials by bone in response to mechanical stress. Science. 1962;137(3535):1063-1064. PubMed PMID: 13865637.

18. Bassett CA, Pawluk RJ, Becker RO. Effects of electric current on bone in vivo. Nature. 1964;204:652-653. PubMed PMID: 14236279 .

19. Ahn AC, Grodzinsky AJ. Relevance of collagen piezoelectricity to 'Wolff's Law': a critical review. Med Eng Phys. 2009;31(7):733-741. PubMed PMID: 19286413. Pubmed Central PMCID: 2771333.

20. Akhtar A, Shami A, Sarfraz M. Functional outcome of tibial nonunion treatment by Ilizarov fixator. Ann Pak Inst Med Sci. 2012;8(3):188-91.

21. Bhandari M, Tornetta P, 3rd, Sprague S, Najibi S, Petrisor B, Griffith L, Guyatt GH. Predictors of reoperation following operative management of fractures of the tibial shaft. J Orthop Trauma. 2003;17(5):353-61. PubMed PMID: 12759640.

22. Gaebler C, Berger U, Schandelmaier P, Greitbauer M, Schauwecker HH, Applegate B, Zych G, Vecsei V. Rates and odds ratios for complications in closed and open tibial fractures treated with unreamed, small diameter tibial nails: a multicenter analysis of 467 cases. J Orthop Trauma. 2001;15(6):415-23. PubMed PMID: 11514768.

23. Karladani AH, Granhed H, Karrholm J, Styf J. The influence of fracture etiology and type on fracture healing: a review of 104 consecutive tibial shaft fractures. Arch Orthop Trauma Surg. 2001;121(6):325-8. PubMed PMID: 11482464.

24. Gaston P, Will E, Elton RA, McQueen MM, Court-Brown $\mathrm{CM}$. Fractures of the tibia. Can their outcome be predicted? J Bone Joint Surg [Br]. 1999;81(1):71-6. PubMed PMID: 10068007.

25. Perumal V, Roberts C. (ii) Factors contributing to non-union of fractures. Curr Orthop. 2007;21(4):258-61.

26. Kyro A, Usenius JP, Aarnio M, Kunnamo I, Avikainen V. Are smokers a risk group for delayed healing of tibial shaft fractures? Ann Chir Gynaecol. 1993;82(4):254-62. PubMed PMID: 8122874

27. Frolke JP, Patka P. Definition and classification of fracture non-unions. Injury. 2007;38 Suppl 2:S19-22. PubMed PMID: 17920413.

28. Zinghi G, Rollo G, Trono M. (eds) La pseudoartrosi della ossa lunghe. 2004 Timeo, Bologna 2004.

29. Megas P. Classification of non-union. Injury. 2005;36 Suppl 4:S30-7. PubMed PMID: 16291321.

30. Brownlow HC, Reed A, Simpson AH. The vascularity of atrophic non-unions. Injury. 2002;33(2):145-50. PubMed PMID: 11890916.

31. Gaston MS, Simpson AH. Inhibition of fracture healing. J Bone Joint Surg [Br]. 2007;89(12):1553-60. PubMed PMID: 18057352

32. Marsh D. Concepts of fracture union, delayed union, and nonunion. Clin Orthop Relat Res. 1998;355 Suppl:S22-30. PubMed PMID: 9917623.

33. Lindaman LM. Bone healing in children. Clin Podiatr Med Surg. 2001;18(1):97-108. PubMed PMID: 11344982.

34. Lu C, Miclau T, Hu D, Hansen E, Tsui K, Puttlitz C, Marcucio RS. Cellular basis for age-related changes in fracture repair. J Orthop Res. 2005;23(6):1300-7. PubMed PMID: 15936915. Pubmed Central PMCID: 2844440.
35. Gruber R, Koch H, Doll BA, Tegtmeier F, Einhorn TA, Hollinger JO. Fracture healing in the elderly patient. Exp Geront. 2006;41(11):1080-93. PubMed PMID: 17092679.

36. Rothman RH. Effect of anemia on fracture healing. Surg Forum. 1968;19:452-3. PubMed PMID: 5718700.

37. Rothman RH, Klemek JS, Toton JJ. The effect of iron deficiency anemia on fracture healing. Clin Orthop Relat Res. 1971;77:276-83. PubMed PMID: 5140454.

38. Heppenstall RB, Brighton CT. Fracture healing in the presence of anemia. Clin Orthop Relat Res. 1977;123:253-8. PubMed PMID: 852180.

39. Varecka TF, Wiesner LL. The influence of acute haemorrhagic anemia on fracture healing. Orthopaedics Today. 2012;15-18; Wailea, Hawaii.

40. Dodds RA, Catterall A, Bitensky L, Chayen J. Abnormalities in fracture healing induced by vitamin B6-deficiency in rats. Bone. 1986;7(6):489-95. PubMed PMID: 3801238.

41. Mohan S, Kapoor A, Singgih A, Zhang Z, Taylor T, Yu H, Chadwick RB, Chung YS, Donahue LR, Rosen C, Crawford GC, Wergedal J, Baylink DJ. Spontaneous fractures in the mouse mutant sfx are caused by deletion of the gulonolactone oxidase gene, causing vitamin C deficiency. J Bone Miner Res. 2005;20(9):1597-610. PubMed PMID: 16059632.

42. Loder RT. The influence of diabetes mellitus on the healing of closed fractures. Clin Orthop Relat Res. 1988;232:210-6. PubMed PMID: 3289812.

43. Macey LR, Kana SM, Jingushi S, Terek RM, Borretos J, Bolander ME. Defects of early fracture-healing in experimental diabetes. J Bone Joint Surg [Am] 1989;71(5):722-33. PubMed PMID: 2659600.

44. Funk JR, Hale JE, Carmines D, Gooch HL, Hurwitz SR. Biomechanical evaluation of early fracture healing in normal and diabetic rats. J Orthop Res. 2000;18(1):126-32. PubMed PMID: 10716288.

45. Gooch HL, Hale JE, Fujioka H, Balian G, Hurwitz SR. Alterations of cartilage and collagen expression during fracture healing in experimental diabetes. Connect Tissue Res. 2000;41(2):81-91. PubMed PMID: 10992154.

46. Beam HA, Parsons JR, Lin SS. The effects of blood glucose control upon fracture healing in the BB Wistar rat with diabetes mellitus. J Orthop Res. 2002;20(6):1210-6. PubMed PMID: 12472231.

47. Kayal RA, Tsatsas D, Bauer MA, Allen B, Al-Sebaei MO, Kakar S, Leone CW, Morgan EF, Gerstenfeld LC, Einhorn TA, Graves DT. Diminished bone formation during diabetic fracture healing is related to the premature resorption of cartilage associated with increased osteoclast activity. J Bone Miner Res. 2007;22(4):560-8. PubMed PMID: 17243865. Pubmed Central PMCID: 3109431.

48. Follak N, Kloting I, Merk H. Influence of diabetic metabolic state on fracture healing in spontaneously diabetic rats. Diabetes Metab Res Rev. 2005;21(3):288-96. PubMed PMID: 15693070

49. Gandhi A, Beam HA, O'Connor JP, Parsons JR, Lin SS. The effects of local insulin delivery on diabetic fracture healing. Bone. 2005;37(4):482-90. PubMed PMID: 16027060.

50. Urabe K, Hotokebuchi T, Oles KJ, Bronk JT, Jingushi S, Iwamoto $Y$, Bolander ME. Inhibition of endochondral ossification during fracture repair in experimental hypothyroid rats. J Orthop Res.1999;17(6):920-5. PubMed PMID: 10632459. 
51. Schmitz MA, Finnegan M, Natarajan R, Champine J. Effect of smoking on tibial shaft fracture healing. Clin Orthop Relat Res.1999;(365):184-200. PubMed PMID: 10627703.

52. Hernigou J, Schuind F. Smoking as a predictor of negative outcome in diaphyseal fracture healing. Int Orthop. 2013;37(5):883-7. PubMed PMID: 23392346. Pubmed Central PMCID: 3631490

53. Patel RA, Wilson RF, Patel PA, Palmer RM. The effect of smoking on bone healing: A systematic review. Bone Joint Res. 2013;2(6):102-11. PubMed PMID: 23836474. Pubmed Central PMCID: 3686151.

54. Scolaro JA, Schenker ML, Yannascoli S, Baldwin K, Mehta S, Ahn J. Cigarette smoking increases complications following fracture: a systematic review. J Bone Joint Surg [Am]. 2014;96(8):674-81. PubMed PMID: 24740664.

55. Adams CI, Keating JF, Court-Brown CM. Cigarette smoking and open tibial fractures. Injury. 2001;32(1):61-5. PubMed PMID: 11164405.

56. Harvey EJ, Agel J, Selznick HS, Chapman JR, Henley MB. Deleterious effect of smoking on healing of open tibia-shaft fractures. Am J Orthop. 2002;31(9):518-21. PubMed PMID: 12650537.

57. Jensen JA, Goodson WH, Hopf HW, Hunt TK. Cigarette smoking decreases tissue oxygen. Arch Surg. 1991;126(9):11314. PubMed PMID: 1929845.

58. Li M, Li Wu Z, Lim Kwong C. Changes in blood supply and bone regeneration induced by nicotine during distraction osteogenesis. Bone. 2008;42(S60).

59. Konno S, Oronsky BT, Semproni AR, Wu JM. The effect of nicotine on cell proliferation and synthesis of secreted proteins in BALB/C 3T3 cells. Biochem Int. 1991;25(1):7-17. PubMed PMID: 1772449.

60. Chen Y, Guo Q, Pan X, Qin L, Zhang P. Smoking and impaired bone healing: will activation of cholinergic anti-inflammatory pathway be the bridge? Int Orthop. 2011;35(9):1267-70. PubMed PMID: 21409368. Pubmed Central PMCID: 3167453.

61. Cobb TK, Gabrielsen TA, Campbell DC, 2nd, Wallrichs SL, Ilstrup DM. Cigarette smoking and nonunion after ankle arthrodesis. Foot Ankle Int. 1994;15(2):64-7. PubMed PMID: 7981802.

62. Schenker ML, Scolaro JA, Yannascoli SM, Baldwin KD, Mehta S, Ahn J. Blowing smoke: A meta-analysis of the effects of smoking on fracture healing and postoperative infection. University of Pennsylvania Orthopaedic Journal. 2013;23:62-3.

63. Castillo RC, Bosse MJ, MacKenzie EJ, Patterson BM, Group LS. Impact of smoking on fracture healing and risk of complications in limb-threatening open tibia fractures. J Orthop Trauma. 2005;19(3):151-7. PubMed PMID: 15758667.

64. Pountos I, Georgouli T, Calori GM, Giannoudis PV. Do nonsteroidal anti-inflammatory drugs affect bone healing? A critical analysis. ScientificWorldJournal. 2012;2012:606404. PubMed PMID: 22272177. Pubmed Central PMCID: 3259713.

65. Su B, O'Connor JP. NSAID therapy effects on healing of bone, tendon, and the enthesis. J Appl Physiol. 2013;115(6):892-9. PubMed PMID: 23869068. Pubmed Central PMCID: 3764618

66. Dodwell ER, Latorre JG, Parisini E, Zwettler E, Chandra D, Mulpuri $\mathrm{K}$, et al. NSAID exposure and risk of nonunion: a meta-analysis of case-control and cohort studies. Calcif Tissue Int. 2010;87(3):193-202. PubMed PMID: 20552333.
67. Giannoudis PV, MacDonald DA, Matthews SJ, Smith RM, Furlong AJ, De Boer P. Nonunion of the femoral diaphysis. The influence of reaming and non-steroidal anti-inflammatory drugs. J Bone Joint Surg [Br]. 2000;82(5):655-8. PubMed PMID: 10963160.

68. Burd TA, Hughes MS, Anglen JO. Heterotopic ossification prophylaxis with indomethacin increases the risk of longbone nonunion. J Bone Joint Surg [Br]. 2003;85(5):700-5. PubMed PMID: 12892193.

69. Bhattacharyya T, Levin R, Vrahas MS, Solomon DH. Nonsteroidal antiinflammatory drugs and nonunion of humeral shaft fractures. Arthritis Rheum. 2005;53(3):364-7. PubMed PMID: 15934108.

70. Davis TR, Ackroyd CE. Non-steroidal anti-inflammatory agents in the management of Colles' fractures. Br J Clin Pract. 1988;42(5):184-9. PubMed PMID: 3063314.

71. Adolphson $\mathrm{P}$, Abbaszadegan $\mathrm{H}$, Jonsson U, Dalen N, Sjoberg HE, Kalen S. No effects of piroxicam on osteopenia and recovery after Colles' fracture. A randomized, double-blind, placebo-controlled, prospective trial. Arch Orthop Trauma Surg. 1993;112(3):127-30. PubMed PMID: 8323840.

72. Vitale MG, Choe JC, Hwang MW, Bauer RM, Hyman JE, Lee FY, Roye DP Jr. Use of ketorolac tromethamine in children undergoing scoliosis surgery. An analysis of complications. Spine J. 2003;3(1):55-62. PubMed PMID: 14589246.

73. Park SY, Moon SH, Park MS, Oh KS, Lee HM. The effects of ketorolac injected via patient controlled analgesia postoperatively on spinal fusion. Yonsei Med J. 2005;46(2):245-51. PubMed PMID: 15861498. Pubmed Central PMCID: 2823021.

74. Sucato DJ, Lovejoy JF, Agrawal S, Elerson E, Nelson T, McClung A. Postoperative ketorolac does not predispose to pseudoarthrosis following posterior spinal fusion and instrumentation for adolescent idiopathic scoliosis. Spine. 2008;33(10):1119-24. PubMed PMID: 18449047.

75. Lumawig JM, Yamazaki A, Watanabe K. Dose-dependent inhibition of diclofenac sodium on posterior lumbar interbody fusion rates. Spine J. 2009;9(5):343-9. PubMed PMID: 18790686.

76. Horn PL, Wrona S, Beebe AC, Klamar JE. A retrospective quality improvement study of ketorolac use following spinal fusion in pediatric patients. Orthop Nurs. 2010;29(5):342-3. PubMed PMID: 20856090.

77. Huddleston PM, Steckelberg JM, Hanssen AD, Rouse MS, Bolander ME, Patel R. Ciprofloxacin inhibition of experimental fracture healing. J Bone Joint Surg [Am]. 2000;82(2):16173. PubMed PMID: 10682725.

78. Perry AC, Prpa B, Rouse MS, Piper KE, Hanssen AD, Steckelberg JM, Patel R. Levofloxacin and trovafloxacin inhibition of experimental fracture-healing. Clin Orthop Relat Res. 2003;(414):95-100. PubMed PMID: 12966282.

79. Pountos I, Georgouli T, Bird H, Kontakis G, Giannoudis PV. The effect of antibiotics on bone healing: current evidence. Expert Opin Drug Saf. 2011;10(6):935-45. PubMed PMID: 21824037.

80. Miclau T, Edin ML, Lester GE, Lindsey RW, Dahners LE. Bone toxicity of locally applied aminoglycosides. J Orthop Trauma. 1995;9(5):401-6. PubMed PMID: 8537843.

81. Isefuku S, Joyner CJ, Simpson AH. Gentamicin may have an adverse effect on osteogenesis. J Orthop Trauma. 2003;17(3):212-6. PubMed PMID: 12621263. 
82. Isefuku S, Joyner CJ, Simpson AH. Toxic effect of rifampicin on human osteoblast-like cells. J Orthop Res. 2001;19(5):950-4. PubMed PMID: 11562146.

83. Street JT, McGrath M, O'Regan K, Wakai A, McGuinness A, Redmond HP. Thromboprophylaxis using a low molecular weight heparin delays fracture repair. Clin Orthop Relat Res. 2000;(381):278-89. PubMed PMID: 11127666

84. Kock HJ, Werther S, Uhlenkott H, Taeger G. [Influence of unfractionated and low-molecular-weight heparin on bone healing: an animal model]. Unfallchirurg. 2002;105(9):791-6. PubMed PMID: 12232738.

85. Solayar GN, Walsh PM, Mulhall KJ. The effect of a new direct Factor Xa inhibitor on human osteoblasts: an in-vitro study comparing the effect of rivaroxaban with enoxaparin. BMC Musculoskelet Disord. 2011;12:247. PubMed PMID: 22035050. Pubmed Central PMCID: 3215189.

86. Lindner T, Cockbain AJ, El Masry MA, Katonis P, Tsiridis E, Schizas C, Tsiridis E. The effect of anticoagulant pharmacotherapy on fracture healing. Expert Opin Pharmacother. 2008;9(7):1169-87. PubMed PMID: 18422474.

87. Pack AM. The Association Between Antiepileptic Drugs and Bone Disease. Epilepsy Curr. 2003;3(3):91-5. PubMed PMID: 15309069. Pubmed Central PMCID: 321183.

88. Pack AM. Bone disease in epilepsy. Curr Neurol Neurosci. 2004;4(4):329-34. PubMed PMID: 15217549.

89. Pack AM, Gidal B, Vazquez B. Bone disease associated with antiepileptic drugs. Cleve Clin J Med. 2004;71 Suppl 2:S42-8. PubMed PMID: 15379299.

90. Valsamis HA, Arora SK, Labban B, McFarlane SI. Antiepileptic drugs and bone metabolism. Nutr Metab (Lond). 2006;3:36. PubMed PMID: 16956398. Pubmed Central PMCID: 1586194.

91. Meier C, Kraenzlin ME. Antiepileptics and bone health. Ther Adv Musculoskelet Dis. 2011;3(5):235-43. PubMed PMID: 22870482. Pubmed Central PMCID: 3383529.

92. Copuroglu C, Calori GM, Giannoudis PV. Fracture nonunion: Who is at risk? Injury. 2013;8. PubMed PMID: 24035757.

93. Pountos I, Georgouli T, Blokhuis TJ, Pape HC, Giannoudis PV. Pharmacological agents and impairment of fracture healing: what is the evidence? Injury. 2008;39(4):384-94. PubMed PMID: 18316083.

94. Waters RV, Gamradt SC, Asnis P, Vickery BH, Avnur Z, Hill E, Bostrom M. Systemic corticosteroids inhibit bone healing in a rabbit ulnar osteotomy model. Acta Orthop Scand. 2000;71(3):316-21. PubMed PMID: 10919307.

95. Boursinos LA, Karachalios T, Poultsides L, Malizos KN. Do steroids, conventional non-steroidal anti-inflammatory drugs and selective Cox-2 inhibitors adversely affect fracture healing? J Musculoskelet Neuronal Interact. 2009;9(1):44-52. PubMed PMID: 19240368.

96. Hogevold HE, Grogaard B, Reikeras O. Effects of short-term treatment with corticosteroids and indomethacin on bone healing. A mechanical study of osteotomies in rats. Acta Orthop Scand. 1992;63(6):607-11. PubMed PMID: 1471505.

97. Chakkalakal DA. Alcohol-induced bone loss and deficient bone repair. Alcohol Clin Exp Res. 2005;29(12):2077-90. PubMed PMID: 16385177.

98. Elmali N, Ertem K, Ozen S, Inan M, Baysal T, Guner G, et al. Fracture healing and bone mass in rats fed on liquid diet containing ethanol. Alcohol Clin Exp Res. 2002;26(4):509-13. PubMed PMID: 11981127.
99. Chakkalakal DA, Novak JR, Fritz ED, Mollner TJ, McVicker DL, Garvin KL, McGuire MH, Donohue TM. Inhibition of bone repair in a rat model for chronic and excessive alcohol consumption. Alcohol. 2005;36(3):201-14. PubMed PMID: 16377462.

100. Obermeyer TS, Yonick D, Lauing K, Stock SR, Nauer R, Strotman P, Shankar R, Gamelli R, Stover M, Callaci JJ. Mesenchymal stem cells facilitate fracture repair in an alcohol-induced impaired healing model. J Orthop Trauma. 2012;26(12):712-8. PubMed PMID: 23010646. Pubmed Central PMCID: 3645443.

101. Askew A, Chakkalakal D, Fang X, McGuire M. Delayed fracture healing in alcohol abusers - A preliminary retrospective study. Open Bone J. 2011;3:1-5.

102. Kamat AS, Govender M. The effects of HIV / AIDS on fracture union. J Bone Joint Surg [Br] 2010;92-B(SUPP I):228.

103. Chandanwale A, Nawale $S$, Bhosale $S$, Jadhav S, Anantraman C. Fracture healing rate in HIV positive patients in India. XVI International AIDS conference. 2006. Toronto, Ontario.

104. Aird J, Noor S, Rollinson P. Is fracture healing affected by HIV in open fractures? J Bone Joint Surg [Br]. 2012;94-B(SUPP XIX):16.

105. Gardner RO, Bates JH, Ng'oma E, Harrison WJ. Fracture union following internal fixation in the HIV population. Injury. 2013;44(6):830-3. PubMed PMID: 23267724.

106. Richardson J, Hill AM, Johnston CJ, McGregor A, Norrish AR, Eastwood D, et al. Fracture healing in HIV-positive populations. J Bone Joint Surg [Br]. 2008;90(8):988-94. PubMed PMID: 18669951.

107.Gershuni DH. Fracture nonunion. Western J Med. 1989;150(6):689-90. PubMed PMID: 2750154. Pubmed Central PMCID: 1026720.

108. Dimitriou R, Kanakaris N, Soucacos PN, Giannoudis PV. Genetic predisposition to non-union: evidence today. Injury. 2013;44 Suppl 1:S50-3. PubMed PMID: 23351872.

109. Zeckey C, Hildebrand F, Glaubitz LM, Jurgens S, Ludwig T, Andruszkow H, Hufner T, Krettek C, Stuhrmann M. Are polymorphisms of molecules involved in bone healing correlated to aseptic femoral and tibial shaft non-unions? J Orthop Res. 2011;29(11):1724-31. PubMed PMID: 21538509.

110. Dimitriou R, Carr IM, West RM, Markham AF, Giannoudis PV. Genetic predisposition to fracture non-union: a case control study of a preliminary single nucleotide polymorphisms analysis of the BMP pathway. BMC Musculoskelet Disord. 2011;12:44. PubMed PMID: 21310029. Pubmed Central PMCID: 3053586.

111. Fajardo M, Liu CJ, Egol K. Levels of expression for BMP-7 and several BMP antagonists may play an integral role in a fracture nonunion: a pilot study. Clin Orthop Relat Res. 2009;467(12):3071-8. PubMed PMID: 19597895. Pubmed Central PMCID: 2772945.

This article is also available online on the SAOA website (www.saoa.org.za) and the SciELO website (www.scielo.org.za). Follow the directions on the Contents page of this journal to access it. 